\title{
JUST WAR AGAINST INFIDELS? SIMILAR ANSWERS FROM CENTRAL AND WESTERN EUROPE
}

\begin{abstract}
The aim of this paper is to take a closer look at the similitudes between the ideas of Paweł Włodkowic (Paulus Vladimiri) and Francisco de Vitoria concerning the relations between Christians and infidels, especially on the issue of just war, and to advance a hypothesis to explain such similarities.

Both scholars come from "frontier States" in the process of expansion and in close contact with non-Christian peoples. They had therefore direct knowledge of these different human groups. The equality between Christians and infidels, the right of all men to property and self-rule as well as their freedom to accept faith, the idea of a community of mankind, are some of the concepts developed by both thinkers. That is why they have been pointed out as beginners of the modern ius gentium. At the end of the paper, I will advance a hypothesis on the influence of Włodkowic on Vitoria.
\end{abstract}

Keywords: Paweł Włodkowic (Paulus Vladimiri); Francisco de Vitoria; ius gentium; just war

1. Two frontier countries. 2. Paweł Włodkowic and Francisco de Vitoria. 3. The nature of the infidels. 4. Religious freedom. 5. Private property and self-rule. 6. The existence of a universal community of humankind. 7. Jus ad bellum. 8. Conclusions.

During the late Middle Ages and early Renaissance, European intellectuals became fully concerned about the relations between Christians and non-Christian peoples, as well as about the conditions for a just war. This paper deals with the ideas of two of these thinkers: Paweł Włodkowic (Paulus Vladimiri) and Francisco de Vitoria, who made significant progress in the development of ius gentium and, especially, on the question of just war.

This article employs a comparative methodology in order to highlight similarities and differences between them. I will argue that the similarities are mainly due to circumstances such as: (1) belonging to "frontier States", in close relations with non-Christian peoples; and (2) relying on similar sources to support their arguments, 
namely some well-known canonists as well as Aquinas. Moreover, I will suggest that Paweł Włodkowic might have influenced Vitoria’s thought.

I will begin by exploring the similarities in the historical situations of the kingdoms of Poland and Spain (1). After giving short biographical information about Włodkowic and Vitoria (2), I will compare their sources and arguments (3). Finally, I will advance a hypothesis about a possible influence of Włodkowic on the Dominican scholar (4).

\section{TWO FRONTIER COUNTRIES}

What were the historical situations in Poland at the beginning of the fifteenth century, and in Spain a hundred years later? Both countries were "frontier" kingdoms in direct relation with non-Christian peoples. In the East, Poland had dealings with Lithuanians, Samogitians, Mongols and Tatars. Castille had always been a frontier kingdom vis $\grave{a}$ vis the Muslim world. By the beginning of the sixteenth century, the Spanish kingdom, recently unified under Charles, conquered the recently discovered American continent and placed it under imperial crown control.

This common condition of "frontier States" is quite important. It shaped political and religious strategies in both countries. In Poland, it allowed fruitful contacts with the east and contributed to the country's exposure to different cultures. Dariusz Kołodziejczyk, in his paper Entre l'antemurale Christianitatis et la raison d'État. L'idée de Croisade en Pologne aux XVe et XVIe siècles, proposes to look at eastern cultures with rich intercultural and inter-religious traditions. He states that they were more open-minded than Western European cultures, which were much more homogenous. ${ }^{1}$ The frontier condition

1 D. Kołodziejczyk, Entre l'antemurale Christianitatis et la raison d'État. L'idée de Croisade en Pologne aux XVe et XVIe siècles, in: L'Europe centrale au seuil de la modernité: Mutations sociales, religieuses et culturelles. Autriche, Bohême, Hongrie et Pologne, fin du 
also meant that Poland was the nation from which the Church hoped to extend to Eastern Europe and Asia.

The Spanish case is different because its "frontier" was another continent, the "New World". This was a much bigger area in which to settle down, establish relations with new people and evangelize them. Nevertheless, the notion of a frontier was deeply imprinted in the Spanish character because of the Reconquista process. The centurieslong coexistence between Christians and Muslims in the Iberian territory made people grow accustomed to live with "others" with different cultures and religions. This fact undoubtedly influenced the process of conquest and colonization of the New World territories.

In both cases, evangelization was a crucial issue and the way to accomplish it a key problem. In Poland, two styles of evangelization were implemented: on the one hand a pacific process carried out by the religious orders settled in Poland; on the other hand conversion through force and armies led by the Teutonic Knights. Włodkowic accused the latter - also called Crucifers - of heresy because they disobeyed the Commandments "Thou shall not kill" and "thou shall not steal". This was one of the arguments used to accuse the Teutonic Order of heresy. ${ }^{2}$

As for Spain, there were long discussions about the way conquerors dealt with the Indians. The complaints reached the Emperor, and the academics from the School of Salamanca gave their opinion on this issue. Francisco de Vitoria wrote: "In truth, if the Indians are not men but monkeys, they are incapable of injury. But if they are men, and our neighbours, and as they claim vassals of the emperor, I cannot see how to excuse these conquistadors of utter impiety and

XIVe siècle - milieu du XVIe siècle. Actes colloque international de Fontrevaud (15-16 mai 2009), Rennes 2010, 19-26.

2 Cf. P. Włodkowic, Opinio Ostiensis, in: L. Ehrlich, Works of Paul Wladimiri, (a selection), Warszawa 1968, I, 128. 
tyranny; nor can I see what great service they do to His Majesty by ruining his vassals."

In this passage, Vitoria affirms the humanity of the Indians. Moreover, he states they are the Emperor's vassals, a condition that Queen Isabella had granted them after Columbus' voyages. Therefore, he accuses the conquerors of tyranny because of the cruelty inflicted, and considers this an act of great injustice that makes restitution obligatory.

In short, both countries were frontier kingdoms deeply involved in the evangelization process, with a group of intellectuals mostly concerned with the fact that non-Christians were being treated inhumanly by Christians. Unjust wars against them and forced conversions led these intellectuals to claim for a change.

\section{PAWEŁ WŁODKOWIC AND FRANCISCO DE VITORIA}

Paweł Włodkowic ${ }^{4}$ (1370-1436) studied law and canons at Prague and Padua, where he was a pupil of the famous canonist Cardinal Zabarella. In 1411, he obtained the degree of Doctor of Decrees and shortly afterwards he was appointed Rector of the Jagiellonian University. The king of Poland sent him on various diplomatic missions, the most important of which was an embassy to the

3 F. de Vitoria, Letter to Padre Arcos, in: Vitoria: Political Writings, red. A. Pagden \& J. Lawrance, Cambridge 2001, 333.

4 For a thorough account of of Paweł Włodkowic’s life and work, see: S. Belch, Paulus Vladimiri and his Doctrine Concerning International Law and Politics, London 1965; L. Chollet, Paul Vladimir (Paweł Włodkowic) au Concile de Constance: une tradition de tolérance religieuse en Pologne et en Lituanie, Paris 2010; K. Ożóg, The Role of Poland in the Intellectual Development of Europe in the Middle Ages, Krakow 2009; F. Russell, Paulus Vladimiri's Attack on the Just War: A Case Study in Legal Polemics, in: Authority and Power: Studies on Medieval Law and Government. Presented to Walter Ullmann on his Seventieth Birthday, red. B. Tierney \& P. Linehan, Cambridge 1980, 237-254; W. Sieradzan, Arguments and Counter-Arguments. The Political Thought of the 14th-15th Centuries during the Polish-Teutonic Order Trials and Disputes, Torun 2012. 
Council of Constance (1414-1418), which was the occasion for his most important writings: Saevientibus and Opinio Ostiensis.

Francisco de Vitoria ${ }^{5}$ (1486-1546) studied theology in Paris and, despite being quite young, was appointed to the Chair of Theology in Salamanca, where he taught until his death. He worked in the Thomist tradition, but was thoroughly open-minded and able to appreciate and integrate new ideas from Christian Humanism. $\mathrm{He}$ is best known for his Relectiones, the lectures that took place on feast days. Among these, De Potestate Civili, De Indis and De Iure Belli are the most famous. However, his regular courses on different parts of Aquinas' Summa Theologiae are also a very important source for studying his views. He did not leave any writings; we only have the notes taken by his students. Vitoria was mainly a moral theologian, though he knew and employed juridical principles in his arguments.

Vitoria's Relectio de Iure Belli is a complete treatise on the subject of war. However, his arguments specifically concerning just war against the infidels are developed in De Indis: that is why I will primarily look at the latter in my analysis of his account.

Notwithstanding the different fields of expertise of these two authors, they have a similar scholastic style of arguing and rely on the same sources: among canonists, they both mention the Decretum Gratiani, the Decretals of Gregory IX, Innocent IV, and Johannes Andreæ. Among theologians, they rely mostly on Thomas Aquinas.

5 There is an extensive bibliography on Francisco de Vitoria's political thought. Some of the latest studies are: J. Cruz Cruz, Delito y pena en el Siglo de Oro, Pamplona,2010; L. Ferrajoli, L'America, la conquista, il diritto. L'idea di sovranità nel mondo moderno, in http://www.rivistameridiana.it/files/Ferrajoli,-L-America,-la-conquista,-il-diritto.pdf; J. Muldoon, Vitoria and Humanitarian Intervention, Journal of Military Ethics 2(2006), 128-143; A. Pagden, La découverte de l'Amérique. La transformation du temps et de l'espace en Europe, Revue de synthèse 129(2008)3, 421-436; I. Trujillo Pérez, Francisco de Vitoria. Il diritto alla comunicazione e i confini della socialità umana, G. Giapichelli Editore, Torino 1997; L. Valenzuela-Vermehren, Vitoria, Humanism and the School of Salamanca in Early Sixteenth-Century Spain. An heuristic overview, Logos 16 (2013)2, 99-125. 


\section{THE NATURE OF THE INFIDELS}

The word "infidel" is a very precise one in the canonical vocabulary. That is why it is necessary to explain how people in the fifteenth and sixteenth centuries understood it. According to Cajetan, a well-known theologian of the early sixteenth century, there are three kinds of infidels:

1. Those dependent de facto and de iure on Christians. They are non-Christians living in Christian territories under their laws.

2. Those dependent only de iure, but not de facto, on Christians. They are non-Christians living in places that belonged to Christians in the past (e.g. Muslims in the Near East).

3. Those dependent neither de iure nor de facto on Christians because they live in territories where Christ is ignored.

Infidels had different rights, depending on the place where they lived. Canonists had different opinions on their rights and obligations, especially for those in the third category above. While Innocent IV stated that infidels remained in possession of their dominions (private and public), Ostiensis claimed they had lost them with the advent of Christ. These two opposite positions were the main views on this issue in the Middle Ages, and both canonists were commented and quoted over several centuries.

Both Włodkowic and Vitoria consider infidels as equal members of the human race, with the same rights and obligations as any other human beings. They want to establish on a firm basis their claim to the humanity of the infidels. While for Włodkowic such a claim results from the thesis that infidels belong to humankind, Vitoria has to prove first of all that Indians are men.

The Polish scholar emphasises the equality between infidels and Christians, grounded in their common human nature. In the Saevientibus, he stresses that all human beings are proximi: Proximi autem nostri secundum veritatem sunt tam fideles quam infideles indistincte. ${ }^{6}$

6 P. Włodkowic, Saevientibus, in: L. Ehrlich, op. cit., I, 59. 
Quoting the great medieval canonist Innocent IV, he says that all men are free by nature and thus capable of dominium:? "infidels can licitly, without sin, have dominions, possessions and jurisdiction, because these have been made not only for the faithful, but for every reasonable creature."

Vitoria also argues for the human nature of American Indians, which was a more delicate issue due to the fact that they looked strange to Europeans in both appearance and way of life. In the first part of his Relectio de Indis, pronounced in Salamanca in 1539, he asks himself "whether these barbarians, before the arrival of the Spaniards, had true dominion, public and private, (...) that is, whether they were true masters of their private chattels and possessions and whether there existed among them any men who were true princes and masters of the others."

In order to prove that the Indians had a right to private and public dominion, he first argues in favour of their being rational: "They have some order (ordo) in their affairs: they have properly organized cities, proper marriages, magistrates and overlords (domini), laws, industries and commerce, all of which requires the use of reason." ${ }^{10}$

Moreover, Vitoria says that if sometimes Indians look savage or primitive, this is due to their lack of education: that is, it is not a problem of nature but a cultural problem. ${ }^{11}$

Both authors rely on the notion of natural law to argue for the equality of Christians and infidels, and quote St. Paul, who said that Gentiles, who had no law, followed the law impressed in their hearts: "For when Gentiles who do not have the law, do by nature the things

7 A. Brett discusses the concept of dominium in Liberty Right and Nature, Cambridge 1997.

8 P. Włodkowic, Saevientibus, in: L. Ehrlich, op. cit., I, 13.

9 F. de Vitoria, Relectio de Indis, in: Vitoria: Political writings, op. cit., I, §4.

10 F. de Vitoria, Relectio de Indis, op. cit., I, §23.

11 This idea is developed in F. Castilla Urbano, El pensamiento de Francisco de Vitoria. Filosofía política e indio americano, Barcelona 1992, 270-271. 
of the law, these, not having the law, are a law to themselves, in that they show the work of the law written in their hearts, their conscience testifying with them, and their thoughts among themselves accusing or else excusing them."12

Włodkowic uses this notion especially to defend the rationality and freedom of conscience of the infidels. Vitoria defends the rationality of the Indians and stresses their responsibility as a free people: that is why he says that if Indians do things that are contrary to natural law, such as human sacrifices, they ought to be punished. ${ }^{13}$

Having clarified the nature of the infidels both authors proceed to explore the consequences of their views.

\section{RELIGIOUS FREEDOM}

"It was by virtue of human free will through which a man was master of his own acts, that he could be master of external things also." ${ }^{14}$ In this passage, Aquinas makes clear that freedom is key to defending not only private and public dominion, but primarily person's acts, among which are religious beliefs.

Włodkowic and Vitoria wanted people to accept faith freely, after good explanations and good examples of a Christian life. Infidels are free and have to decide whether or not to accept Christianity as their religion. If they choose not not accept it, this is not enough to set war against them. To support their views both authors refer to Gratian, who argues that the best way to lead infidels to conversion is the use of soft methods: Non asperis, sed blandis verbis, ad fidem sunt aliqui provocandi. ${ }^{15}$ Later on, Innocent IV writes: Item licet non debeant

12 Rom, 2, 14-15.

13 Cf. F. de Vitoria, Relectio de Indis, op. cit., III, §15.

14 St. Thomas Aquinas, Sth, Ila-Ilae, q. 66, 1.

15 Decretum Gratiani, dist. XLV, C. III. 
infideles cogi ad fidem, qua omnes libero arbitrio relinquendi sunt, et sola Dei gratia in hac vocatione valet. ${ }^{16}$

Both authors maintain that faith must be received by free spirits. Therefore, it must be preached without force. In the Saevientibus, Vladimiri writes: "It is not allowed to compel infidels by arms or oppressions to embrace the Christian faith, for to take this way is to wrong our neighbour, and bad things must not be done in order that good things should result." ${ }^{7}$

In the Relectio de Indis, Vitoria states that faith should be preached in non-violent ways and that preachers should accompany the Christian message with the example of their virtuous life, a recommendation that has often been overlooked in the evangelization process: "From this, it does not appear that the Christian religion has been preached to them in a sufficiently pious way to oblige their acquiescence, even though many religious and other ecclesiastics seem both by their lives and example and their diligent preaching to have bestowed sufficient pains and industry in this business." 18

Regardless, if the infidels refused to convert this would be no cause for war. "19 "However probably and sufficiently the faith may have been announced to the barbarians and then rejected by them, this is still no reason to declare war on them and despoil them of their goods." This conclusion is expressed by St Thomas in his Summa Theologiae II-II, 8, where he says that unbelievers who have never taken up the faith such as pagans and Jews cannot be obliged to accept it. ${ }^{20}$ Both authors quote a canon about the Jewish (c. 5 De Iudaeis, dist. 45) in support of their views.

Infidels, however, have an obligation to receive preachers. Vitoria says this obligation follows from the right to communicate ideas,

16 Innocent IV, Super Libros Quinque Decretalium, III, tit XXXIII, cap VIII, 430 v.

17 P. Włodkowic, Saevientibus, in: L. Ehrlich, op. cit., I, 8.

18 F. de Vitoria, Relectio de Indis, op. cit., II, §14.

19 Ibidem, II, §15.

20 Ibidem, II, §39. 
whereas Włodkowic thinks that, according to the natural law everyone must worship the true God. Failure to receive preachers could be a just cause for war, to be decided by the pope. ${ }^{21}$ Here Włodkowic relies on religious arguments combined with purely juridical ones. He thinks that infidels must allow preachers in their territory because the true God must be worshipped, but this contradicts his earlier argument that faith is the result of free decision. Truth was above freedom in medieval times, and Włodkowic is a medieval man.

On the issue of liberty of conscience and religious toleration, there is a clear difference between Włodkowic and Vitoria. Probably due to historical circumstances - Vitoria lived during the Reformation the Spanish scholar did not speak at all about religious toleration, but only about the problem of the conversion of the Indians. On the other hand Włodkowic, who lived in a country surrounded by infidels, schismatics like the Hussites, and Orthodox, had to think about toleration and have an opinion about this important matter. He thought that it was preferable to maintain a friendly relationship with people of different religions, because he understood that in this way they would more easily come to the true faith. At the Council of Constance he worked hard to try to reunify the Churches of the East and West, which was not possible at the time.

\section{PRIVATE PROPERTY AND SELF-RULE}

Was it allowed to begin a war in order to take over lands inhabited by infidels? Some medieval intellectuals (e.g. Cardinal Ostiensis) maintained that infidels had no dominion, and for that reason it was lawful for Christians to take over the lands where they lived. On the contrary, Innocent IV wrote that property (dominium) was a right according to the natural law of reason; "civil law provided only the forms of action through which property claims were pursued in court.

21 P. Włodkowic, Opinio Ostiensis, in: L. Ehrlich, op. cit., I, 124. 
Hence (...) governments should not arbitrarily deprive their citizens of property; a law in violation of a natural right was not valid unless some just cause intervened." 22

Innocent also argued, in a very influential passage, that all peoples, even infidels, had a right to acquire property and to form their own governments. He wrote that God subjected all things to the dominion of man as a rational creature. At first all was held in common, but "property was introduced by occupation of things in bonis nullius or by agreements." 23

Canonists and lawyers of the time, who had studied this issue, thought that the division of properties was a law of ius gentium. It became necessary because of original sin. It also assured that the land would be well cared for and laboured. The existence of private dominium was, therefore, a proof of reasoning and, thus, of humankind. Some well-known canonists, such as Ostiensis, said that when Jesus came to earth, all previous dominium ceased and only Christians had the true dominium. This idea was accepted by many academics. Włodkowic dedicates a whole text to refute it - the Opinio Ostiensis - where he writes: Verum quia hec opinio videtur sediciosa et dat viam ad multas strages in populo et eciam ad rapinas commitendas quia si non sunt domini istorum licebit cuilibet ea occupare et rapere etc., videtur igitur dec mageria plena periculis necessario declaranda per hoc sacrum concilium. ${ }^{24}$ Vitoria also writes against Ostiense's views in his Relectiones. ${ }^{25}$

Both Włodkowic and Vitoria insist that infidels have res publicae rightly established, with appropriate governors and laws, and that it is not lawful to despoil their governments. They had to argue against papal donations of infidel lands and government possessions

22 B. Tierney, The idea of natural rights. Studies on natural rights, natural law, and church law, 1150-1625, Grand Rapids (MI) 2005, 143.

23 Ibidem, 144.

24 P. Włodkowic, Opinio Ostiensis, in: L. Ehrlich, op. cit., I, 113-114.

25 Cf. F. de Vitoria, Relectio de Indis, op. cit., II, §2. 
to Christians. In the Polish case, the Emperor was also responsible for some of these donations. The arguments they used were similar.

Włodkowic writes: "Every one of these donations was by law void, because made as to something that was not one's own; for another's thing cannot be donated (...), for it is neither valid if done to the prejudice of the true owner, for what one has not, one cannot transfer to another." 26

He affirms that infidels have true reigns and governments, and that Christians have no right to despoil them from their legitimate authorities. The division in political communities is a ius gentium principle, and each must respect the others and live in peace with all of them. Moreover, pagan kingdoms are legitimate and can be allies of Christian kingdoms in just wars.

In the Spanish case, the main problem was that kings relied on papal donations of American land as a legitimate title for their presence in the New World. Vitoria explains the nature of the pope's authority and the limits of his jurisdiction. He emphasises that the land belonged legitimately to the Indians, and that the pope was not the lord of the world, and had no power to donate land that was not his: "The pope is not the civil or temporal lord of the whole world in the proper sense of the words lordship and civil power."27

This is undoubtedly one of Vitoria's most notable contributions to European thought, and one that makes him a truly modern thinker. He succeeds in distinguishing the secular from the spiritual, and tries to ensure a sphere of autonomy for secular matters.

Włodkowic and Vitoria agree in defending the private and public dominion of the infidels. Therefore, the wars (either launched by the Crucifers or the Spanish conquerors) motivated by a refusal to recognize this right were declared unjust by both thinkers.

26 P. Włodkowic, Ad aperiendam, in: L. Ehrlich, op. cit., I, 234-235.

27 F. de Vitoria, Relectio de Indis, op. cit., II, §3. 


\section{THE EXISTENCE OF A UNIVERSAL COMMUNITY OF HUMANKIND}

Włodkowic and Vitoria acknowledge a community of all human beings, regardless of race, place of birth or religion. This new kind of community is called by Paweł Włodkowic societas humanae and by Vitoria totius orbis. Both ground it in the common condition of all human beings, on their equality, and on friendship, which is the natural relationship among them. Surprisingly, they quote the same verse of the Scripture to signify this reality: "All animal loves its kind" (Eccli 13). They consider friendship between Christians and infidels as part of the natural law.

Having established the existence of such a community, both authors draw some conclusions. In the first place, they think friendship is the basis for legitimate alliances with infidels. Włodkowic defends the legitimacy of the alliance between Poles and their pagan neighbours against the Crucifers. In the Saevientibus, he asks whether "a Christian may without sin use the aid of infidels for the defense of himself and his land". In his answer, he recalls Johannes Andrex: "I consider that pacific infidels, (...) can in case of imminent necessity licitly be called upon". To this he adds: "Likewise, conversely, in a just war infidels are aided by the faithful." 28

In his response to the Crucifers, Quoniam error, the Cracovian master develops this argument. He says the relationship with infidels is not prohibited because the law of the societas humanae establishes it, that is, he puts the natural law over positive laws, ecclesiastical or civil. The Polish alliance with the infidels against the Crucifers is, therefore, legitimate. ${ }^{29}$

Similarly, Vitoria states: "There can be no doubt that fighting on behalf of allies and friends is a just cause of war, as Cajetan declares

28 P. Włodkowic, Saevientibus, in: L. Ehrlich, op.cit., I, 75-76.

29 Idem, Quoniam error, in: L. Ehrlich, op. cit., II, 389. 
(in ST II.II. 40.1 § 5); equally, a commonwealth may call upon foreigners to punish its enemies and fight external malefactors." ${ }^{30}$

Friendship is also a main reason for an intervention in defense of innocents, what we nowadays call humanitarian intervention. ${ }^{31}$ This would be a just cause for war, in Vitoria's thought: "Another possible title is founded either on the tyranny of those who bear rule among the aborigines of America or on the tyrannical laws which work wrong to innocent folk there, such as that which allows the sacrifice of innocent people or the killing in other ways of uncondemned people for cannibalistic purposes." ${ }^{2}$

For Włodkowic, the universal community is not yet clearly delineated. However, one thing is clear: he considers that there must be a judicial authority to decide over conflicts between peoples. This is a trace of the true community, with true power.

In Vitoria's case, communitas orbis is better conceived. He claims that the world is "somehow a republic" - "aliquo modo est respublica" 33 and draws an analogy between the respublica and the orbis. This communitas has its people (all inhabitants of the world), its law (the law of the nations), its goal (the universal common good), and its authority.

Justenhoven points out that Vitoria is the first author to use the world orbis to refer to the whole world: "Originally, the term orbis was used to describe the universal empire. (...) Using the classical term orbis, Vitoria could make sure that his contemporaries understood that he was talking about the New World in a sense that it was to be part of the same community as the Old World. Old and New World,

30 F. de Vitoria, Relectio de Indis, op. cit., III, §17.

$31 \mathrm{~W}$. Bain discusses this issue in relation to contemporary problems in Saving the Innocent, Then and Now: Vitoria, Dominion, and World Order, History of Political Thought 34(2013)4, 3-5.

32 F. de Vitoria, Relectio de Indis, op. cit., III, §15.

33 F. de Vitoria, De Potestate Civili, in: Vitoria: Political Writings, op. cit., §21. 
this is Vitoria's key message, are to be understood as one community in a similar way as the old orbis was." ${ }^{4}$

Vitorias' reasoning has in this feature its point of departure. This definition of orbis comes from his De potestate civili (1528), one of his first public lectures as professor at Salamanca. Victoria goes on to argue that the world has the right to enforce laws, which are those of ius gentium. Based on this idea of a universal respublica with a corpus of laws, he formulates his arguments about the proper and just relations among peoples inside this republic.

One of the key features of such a communitas orbis is the existence of a common corpus of laws called ius gentium: "that which natural reason has established among all men, which is respected equally by all men, and is called ius gentium, the right that all peoples use." ${ }^{35}$

In Roman times ius gentium was the law applied to private relations between Romans and foreigners, and was assumed to be grounded in reason. When a universal community began to be conceived, it started to be considered as the corpus of law applied to the relations among peoples. The contributions of medieval canonists as well as that of Vitoria were essential to bring about this shift in meaning.

Considering ius gentium, the Spanish scholar analyses what he calls the "right to sociability and communication", which for him comprises the rights to trade, travelling, and migration, as well as the right to communicate ideas, particularly religious ones. "If the Spaniards have a right to travel and trade among the Indians, they can teach the truth to those willing to hear them, especially as regards matters pertaining to salvation and happiness." ${ }^{36}$

Another important issue that concerns the universal community is the question of authority. In Włodkowic's view there is a kind of universal community of kingdoms, united by ius gentium and by

34 H. Justenhoven, From Just War to Modern Peace Ethics, Berlin 2012, 128.

35 Inst. lust. 1, 2, 1.

36 F. de Vitoria, Relectio de Indis, op. cit., III, §9. 
the Pope's authority. He can punish infidels if they do not obey natural laws. ${ }^{37}$ The universal authority has a judicial role in conflict resolution. Every country must refer to this court to be sure of the legitimacy of its demand of just war. There is a "prohibition of unilateral decisions on the justice of one's own case and on the admissibility of selfdefence: only a decision of a competent court authorizes the use of force, even against a lawless attack." ${ }^{38}$ In addition to being the supreme head of the Church, the Pope is also the judge in case of troubles between kingdoms and can punish infidels if they do not obey the natural law. ${ }^{39}$

Vitoria's analysis of the way a universal authority would act in the frame of the communitas orbis is not very clear. In fact, I think this is one of the weakest parts of his relectio on just war. According to Vitoria, once the prince has defeated his enemies (he thinks the winner will always be the just one) he will be the arbitrator in the dispute between his own kingdom and his enemy's. The prince can forego personal advantages, and rightly judge between the parties involved. This is clearly utopian.

\section{JUS AD BELLUM}

The question of the justice of war or jus ad bellum was posed by St. Augustine and, from that time on, many medieval philosophers and jurists wrote about it. The question was further specified in the twelfth century, in the Decretum Gratiani, and later, in the work of Raymond de Peñafort and other lawyers and canonists. Aquinas summarized all this research on just war in his Summa Theologia. War was considered as a moral question and a question of justice: that is why both theologians and jurists dealt with it. The reasons that could

37 P. Włodkowic, Opinio Ostiensis, in: L. Ehrlich, op. cit., I, 122-123.

38 L. Ehrlich, Works of Paul Wladimirii op. cit., LVIII.

39 S. Belch, Paulus Vladimiri and his doctrine, op. cit., 318. 
justify a war were specified by five criteria: "persona, res, causa, animus and auctoritas". This meant that only lay people could go to war; that only an aggression or an in-iuria could be considered as a just cause; that people should go to war with the right intention(not for revenge, but to restore justice); and that a war was lawful only when declared by the authority. These criteria provided a good framework to evaluate Medieval warfare and, with small modifications, continued to be used in the following centuries.

The new conception of communitas orbis contributes to a better understanding of the idea of a just war. In this framework, war is seen as a failure in communication. It is not merely a question of iniuria of one people to another, but rather a question of inuria to world peace and the common good. When a prince goes to war, he represents the totius orbis and his mission is to restore peace and justice, which have been endangered by another governor. Vitoria develops this idea in his Relectio De Iure Belli. After stating that "there is a single and only just cause for commencing a war, namely, a wrong received, ${ }^{\prime 40}$ he goes on to say that war should be started bearing in mind the "good of the whole world. There would be no condition of happiness for the world, nay, its condition would be one of utter misery, if oppressors and robbers and plunderers could with impunity commit their crimes and oppress the good and innocent, and these latter could not in turn retaliate on them." ${ }^{31}$

According to both Vitoria and Włodkowic, there can be no just war against infidels based only on religious differences. ${ }^{42}$ Vladimiri recalls the arguments put forth by Raymond de Peñafort ${ }^{43}$ and criticizes Ostiensis, who defends the thesis that any war against infidels who do not recognize the Emperor or the Pope is a just one. ${ }^{44}$ Vitoria condemns

40 F. de Vitoria, Relectio de Iure Belli, in: Vitoria: Political Writings, op. cit., §13.

41 Ibidem, §1.

42 Ibidem, $\$ 10$.

43 P. Włodkowic, Opinio Ostiensis, in: L. Ehrlich, op. cit., I, 130-131.

44 Ibidem, 113. 
the Spanish conquerors who would wage war against defenceless Indians when they do not accept the Christian faith.

The iniuria considered by these authors are the failure to receive preachers and the damage done to other persons or peoples (e.g. human sacrifices). I Imposing the Christian faith, ravaging territories and goods, and deposing local governors are explicitly excluded from the idea of a just war and firmly condemned.

Włodkowic and Vitoria succeed in applying just war theories to shed light on pressing problems of their time, including the activities of the Teutonic Knights and the behaviour of the Spanish conquerors in America.

\section{CONCLUSIONS}

In this paper, I have tried to draw a parallel between the views of Paweł Włodkowic and Francisco de Vitoria on the issues of ius gentium, infidel rights and just war.

Historical analogies and especially a common intellectual background have been pointed out as the sources of the similarities between their accounts. Their ideas on the nature of the infidels, the legitimate way of preaching and receiving the faith, the community of mankind, and just war show that they share a rich common ground despite geographical and political differences.

Although their similarities can be explained through this common ground, it is also possible to advance another hypothesis. Could Paweł Włodkowic have had an influence on Vitoria? Did Vitoria become acquainted with Włodkowic's writings during his studies in Paris? Authors like Winiarsky, Wielgus, Belch, Muldoon and Dufour ${ }^{45}$

45 Vid. A. Dufour, Droit international et chrétienté: des origines espagnoles aux origines polonaises du droit international. Autour du sermon De bellis justis du canoniste polonais Stanisłas de Skarbimierz (1360-1431), in: The Roots of International Law / Les fondements du droit international. Liber Amicorum Peter Haggenmacher, red. P. Dupuy, V. Chetail, Brill on line Source, 2013, 95-119, http://catalog.lib.ku.edu/cgi-bin/Pwebrecon. 
discuss this issue. Some of them do suggest Vitoria could have beeen influenced by Włodkowic, yet no one has proved it. The question is still open for research.

In any case, the similarities between both thinkers disclose new ways of dealing with the problem of "the Other" in the late Middle Ages, and enable us to consider European thought as a whole, much more connected than we initially believed.

\section{BIBLIOGRAPHY}

Bain W., Saving the Innocent, Then and Now: Vitoria, Dominion, and World Order, History of Political Thought 34(2013)4, 588-613.

Belch S., Paulus Vladimiri and his doctrine concerning international law and politics, Mouton \& Co., The Hague 1965.

Brennan T., Just War, Sovereignty, and Canon Law: Legal Arguments over the Lithuanian Crusade and the Rights of Unbelievers at the Council of Constance (1414-1418), PhD Thesis, University of Kansas 2005.

Brett A., Liberty, Right and Nature, Cambridge University Press, Cambridge 1997. Castilla Urbano F., El pensamiento de Francisco de Vitoria. Filosofía politica e indio americano, Anthropos, Barcelona 1992.

Chollet L., Paul Vladimir (Pawet Wtodkowic) au Concile de Constance: une tradition de tolérance religieuse en Pologne et en Lituanie, Université de Neuchâtel, Faculté des Lettres et Sciences Humaines, Institut d'Histoire, Mémoire 2010, pro manuscripto.

Cruz Cruz J., Delito y pena en el Siglo de Oro, EUNSA, Pamplona 2010.

Dufour A., Droit international et chrétienté: des origines espagnoles aux origines polonaises du droit international. Autour du sermon De bellis justis du canoniste polonais Stanistas de Skarbimierz (1360-1431), red. Dupuy, P. \& Chetail, The Roots of International Law/Les fondements du droit international. Liber Amicorum Peter

cgi?bbid=5348770 [accessed 26.V.2015]; S. Wielgus, The Medieval Polish Doctrine of the Law of Nations: Ius Gentium, Lublin 1998; J. Wos, Un débat ouvert: Paulus Wladimiri et Francisco De Vitoria, Mediaevalia Philosophica Polonorum 21(1975), 85-88; J. Muldoon, The Contribution of the Medieval Canon Lawyers to the Formation of International Law, Traditio 28(1972); S. Belch, Paulus Vladimiri and his Doctrine Concerning International Law and Politics, London 1965; B. Winiarski, Vitoria et Włodkowic, Bulletin international de l'Académie Polonaise des Sciences et des Lettres 1936, 242-247. 
Haggenmacher, Brill on line Source, 2013, 95-119, http://catalog.lib.ku.edu/ cgi-bin/Pwebrecon.cgi?bbid=5348770.

Ehrlich L., Works of Paul Wladimiri (a selection), 3 vol., Instytut Wydawniczy Pax, Warsawa 1968.

Ferrajoli L., L'America, la conquista, il diritto. L'idea di sovranità nel mondo moderno, http://www.rivistameridiana.it/files/Ferrajoli,-L-America,-la-conquista,-ildiritto.pdf.

Ferrajoli L., La soberania en el mundo moderno, in: Derechos y garantías. La ley del más débil., Trotta, Madrid 2004, 125-175.

From Just War to Modern Peace Ethics, ed. H.-G. Justenhoven \& W.A. Barbieri, Walter de Gruyter Gmbh \& Co, Berlin 2012.

Kołodziejczyk D., Entre l'antemurale Christianitatis et la raison d'État. L'idée de Croisade en Pologne aux XVe et XVIe siècles, in: L'Europe centrale au seuil de la modernité: Mutations sociales, religieuses et culturelles. Autriche, Bohême, Hongrie et Pologne, fin du XIVe siècle - milieu du XVIe siècle. Actes colloque international de Fontrevaud (15-16 mai 2009), Rennes 2010, 19-26.

Muldoon J., The Contribution of the Medieval Canon Lawyers to the Formation of International Law, Traditio 28(1972), 483-497.

Muldoon J., Vitoria and Humanitarian Intervention, Journal of Military Ethics 2(2006), 128-143.

Ożóg K., The Role of Poland in the Intellectual Development of Europe in the Middle Ages, Societas Vistulana, Krakow 2009.

Pagden A., La découverte de l'Amérique. La transformation du temps et de l'espace en Europe, Revue de synthèse 129(2008)3, 421-436.

Pena M.A., La Escuela de Salamanca. De la Monarquía bispánica al Orbe Católico, Universidad de Salamanca, Salamanca 2009.

Sieradzan W., Arguments and Counter-Arguments. The Political Thought of the 14th-15th Centuries during the Polish-Teutonic Order Trials and Disputes, Wydawnictwo Uniwersytetu Mikolaja Kopernika, Torun 2012.

Tierney B., The idea of natural rights. Studies on natural rights, natural law, and church law, 1150-1625, William B. Eerdmans Publ., Grand Rapids (MI) 2005.

Tierney B., Linehan P., Authority and Power: Studies on Medieval Law and Government. Presented to Walter Ullmann on his Seventieth Birthday, Cambridge University Press, Cambridge 1980.

Trujillo Pérez I., Francisco de Vitoria. Il diritto alla comunicazione e i confini della socialità umana, G. Giapichelli Editore, Torino 1997.

Tubau X., Canon Law in Juan Ginés de Sepúlveda's "Democrates Secundus", Bibliothèque d'Humanisme et Renaissance 73(2011)2. 
Valenzuela-Vermehren L., Vitoria F., Humanism and the School of Salamanca in Early Sixteenth-Century Spain. An heuristic overview, Logos 16(2013)2, 99-125. Vitoria F., De Indis et De Ivre Belli Relectiones Being Parts of Relectiones Theologicae XII (Nys, John ed.), Oceana Publications, New York 1964.

Vitoria F., Political Writings, red. A. Pagden, A. \& J. Lawrance, Cambridge University Press, Cambridge 2001.

Wielgus S., The Medieval Polish Doctrine of the Law of Nations: Ius Gentium, Catholic University of Lublin, Lublin 1998.

Winiarski B., Vitoria et Wtodkowic, Bulletin international de l'Académie Polonaise des Sciences et des Lettres (1936), 242-247.

Wos J., Un débat ouvert: Paulus Wladimiri et Francisco de Vitoria, Mediaevalia Philosophica Polonorum 21(1975), 85-88.

\author{
Bárbara Díaz \\ BDiaz@uandes.cl \\ Universidad de los Andes, Chile, History Institute \\ Álvaro del Portillo 12455, Las Condes, Santiago de Chile \\ DOI: 10.21697/spch.2017.53.3.03
}

